\title{
Sistem Monitoring Kognitif, Afektif dan Psikomotorik Siswa Berbasis Android
}

\author{
Lorenzo M. Kasenda, Steven R. Sentinuwo, Virginia Tulenan \\ Teknik Informatika Universitas Sam Ratulangi. Manado, Indonesia \\ kasendalorenzo@gmail.com, steven@unsrat.ac.id, virginia.tulenan@unsrat.ac.id
}

\begin{abstract}
Abstrak - Skripsi ini berisi tentang proses pembuatan aplikasi mobile berbasis android, dimana aplikasi ini mempermudah pekerjaan para guru di sekolah dalam hal memonitoring dan mengevaluasi tiga aspek penting dalam pembelajaran para peserta didik yaitu aspek kognitif, afektif, dan psikomotorik. Aplikasi ini bertujuan untuk membantu para guru dalam memonitoring ketiga aspek pembelajaran tersebut dengan cepat dan mudah dengan mengandalkan kemampuan smartphone saat ini. Metodologi yang digunakan dalam pembuatan aplikasi mobile ini adalah RAD (Rapid Application Development) yang meliputi empat tahap kerja yaitu analisis persyaratan, analisis modeling, desain modeling dan konstruksi. Aplikasi mobile ini diharapkan bisa menjadi solusi atas kelemahan - kelemahan yang ada pada sistem monitoring yang dipakai oleh sekolah - sekolah saat ini.
\end{abstract}

Kata kunci: Monitoring, Mobile, Android.

\section{PENDAHULUAN}

Monitoring siswa merupakan salah satu kegiatan yang dilakukan oleh pihak sekolah dan dalam memantau dan mengevaluasi ketiga aspek dalam proses pembelajaran siswa. Setiap sekolah melakukan monitoring dengan cara yang berbeda-beda. Jika kita melihat beberapa tahun silam, proses monitoring siswa sebenarnya cukup sederhana. Apabila seorang siswa melanggar aturan atau berbuat baik, guru di bagian kesiswaan akan mencatat aktivitas yang sudah dilakukan oleh siswa yang bersangkutan ke dalam sebuah buku dan akan terus mencatat tindakan yang dilakukan siswa tersebut sampai akhir semester.

Beberapa tahun berikutnya, ketika dunia pendidikan kita sudah banyak memanfaatkan komputer, proses monitoring akan dilakukan dengan bantuan software spreadsheet misalnya Microsoft Excel, kemudian di akhir semester hasil monitoring tersebut dapat dijadikan acuan dalam mengevaluasi siswa - siswinya. Proses monitoring yang telah memanfaatkan pencatatan dengan software spreadsheet masih banyak dijumpai kelemahan diantaranya integritas data dimana file yang disimpan ada kemungkinan terhapus secara tidak sengaja, atau juga corrupt sehingga tidak dapat diakses lagi. Ada juga keamanan data dimana file masih dapat dibobol ataupun disalahgunakan oleh pihak yang tidak berkepentingan juga single user dimana file - file tersebut hanya bisa diinput oleh satu orang saja sehingga menjadi beban tersendiri bagi para guru yang dipercayakan memegang tugas tersebut.

Tujuan pembuatan aplikasi ini yaitu untuk mengatasi kelemahan - kelemahan yang ada pada sistem saat ini sehingga dengan adanya aplikasi ini integritas data menjadi lebih baik dimana data terpusat pada satu server, memiliki sekuritas data yang baik agar data - data yang ada akan tersimpan secara aman dan terutama dapat dilakukan oleh seluruh pihak guru di sekolah.

Untuk itu dirancanglah aplikasi sistem monitoring aspek kognitif, afektif, dan psikomotorik siswa berbasis android, sebagai salah satu alat bantu para guru dalam memonitoring siswa - siswi di sekolah. Android menjadi pertimbangan dalam mengembangkan aplikasi ini karena perangkat ini paling banyak digunakan. Aplikasi ini nantinya dapat diakses oleh para guru untuk memantau aktivitas siswa - siswi di sekolah, mencatat tingkah laku yang dibuat oleh siswa baik itu dikelas maupun diluar kelas dan data yang disimpan tersebut akan dicatat kedalam database. Data - data yang disimpan ini nantinya akan diakumulasi di akhir semester sehingga bisa menjadi acuan untuk mengevaluasi siswa - siswi di sekolah.

\section{LANDASAN TEORI}

A. Kognitif, Afektif dan Psikomotorik

B. S. Bloom (1956) berpendapat bahwa tujuan pendidikan itu harus senantiasa mengacu kepada tiga ranah yang melekat pada diri peserta didik yaitu ranah proses berfikir (kognitif), ranah nilai atau sikap (afektif), dan ranah keterampilan (prikomotorik). ${ }^{[1]}$

Ranah kognitif merupakan ranah yang berkaitan dengan aspek - aspek intelektual atau berpikir/nalar. Didalamnya mencakup pengetahuan, pemahaman, 
penerapan, penguraian, pemaduan, dan penilaian (M. M. Solichin, 2012). Dalam ranah kognitif, sejauh mana peserta didik dan pada level yang lebih atas seorang peserta didik mampu menguraikan kembali kemudian memadukannya dengan pemahaman yang sudah ia peroleh untuk kemudian diberi penilaian/pertimbangan. ${ }^{[2]}$

Ranah afektif merupakan ranah yang berkaitan dengan aspek - aspek emosional seperti perasaan, minat, sikap, kepatuhan terhadap moral. Didalamnya mencakup penerimaan, sambutan, tata nilai, pengorganisasian, dan karakterisasi (L. W. Andersen, 1981). Dalam ranah ini peserta didik dinilai sejauh mana ia mampu menginternalisasikan nilai - nilai pembelajaran ke dalam dirinya. Ranah ini erat kaitannya dengan tata nilai dan konsep diri. ${ }^{[3]}$

Ranah psikomotorik merupakan ranah yang berkaitan dengan aspek - aspek keterampilan yang melibatkan fungsi sistem saraf dan otot dan berfungsi psikis. Ranah ini terdiri dari kesiapan, peniruan, membiasakan, menyesuaikan, dan menciptakan (M. Haryati, 2009). Ketika peserta didik telah memahami dan menginternalisasikan nilai - nilai mata pelajaran dalam dirinya, maka tahap selanjutnya adalah bagaimana peserta didik mampu mengaplikasikan pemahamannya dalam kehidupan sehari - hari melalui perbuatan atau tindakan. ${ }^{[4]}$

Ketiga ranah diatas yang lebih dikenal dengan istilah head (kepala), heart (hati), dan hand (tangan) merupakan kriteria yang dapat digunakan oleh pendidik untuk mengetahui tingkat keberhasilan proses pembelajaran.

\section{B. Monitoring}

Monitoring adalah kegiatan yang dilakukan untuk mengecek penampilan dari aktivitas yang sedang dikerjakan (Soekartawi, 1995). Menurut Soekartawi (1995), monitoring lebih cenderung bersifat "pengawasan", yaitu melakukan kegiatan pengawasan terhadap jalannya proyek ${ }^{[5]}$. Kegiatan monitoring sering dilaksanakan bersamaan dengan kegiatan evaluasi. Hal ini disebabkan karena kegiatan evaluasi suatu proyek tidak selalu harus dikerjakan pada saat proyek tersebut selesai, tetapi juga pada saat awal, pertengahan, menjelang proyek tersebut selesai atau setelah proyek tersebut selesai seluruhnya. Pekerjaan monitoring dapat dilakukan berkali-kali selama proyek berlangsung dan kegiatan ini sangat tergantung dari dana yang disediakan untuk kegiatan tersebut. Monitor pelaksanaan suatu proyek adalah upaya meliputi perkembangan atau proses suatu kegiatan serta hasil yang dicapai. Dengan pengertian ini, maka ada dua hal yang perlu dimonitor, yaitu :

i) Perkembangan atau proses dari suatu kegiatan.

ii) Hasil yang dicapai dari pelaksanaan kegiatan tersebut
Adapun subjek penilaian yang sudah diatur terbagi menjadi dua kategori yaitu subjek positif dan negatif. Subjek positif memiliki poin plus sedangkan subjek negatif memiliki poin minus.

Semakin besar poin yang dimiliki oleh peserta didik maka semakin baik penilaiannya. Sebaliknya semakin kecil poin yang dimiliki siswa maka semakin buruk penilaianya. Apabila peserta didik telah mencapai poin -25 maka akan diberikan teguran lisan oleh wali kelas atau guru kesiswaan. Jika poin siswa di akhir semester lebih dari -25 akan diberikan sanksi berupa:

a) Pemanggilan orang tua siswa dan membuat pernyataan tertulis bila mencapai pelanggaran dengan bobot poin -31 sampai 40

b) Peringatan/ Pernyataan 1 bila mencapai bobot poin : -41 sampai -60

c) Peringatan/ Pernyataan 2 bila mencapai bobot poin : -61 sampai -85 , Serta mebuat peryataan diatas materai Rp.6000, apabila mencapai pelanggaran dengan bobot poin -85

d) Peringatan/ Pernyataan 3, skorsing 2 hari, bila mencapai bobot poin : -86 sampai -100

e) Dikembalikan kepada orang tua apabila bobot poin pelanggaran mencapai -100 atau lebih. Untuk mengembalikan siswa kepada orang tua atau mengeluarkan peserta akan diadakan rapat luar biasa yang melibatkan wali kelas, guru BK, wakil/ staf kesiswaan,, dan Kepala Sekolah.

C. Android

Android merupakan Sistem Operasi berbasis Linux yang digunakan untuk smartphone dan komputer tablet. Android menyediakan platform terbuka bagi para pengembang untuk menciptakan atau mengembangkan aplikasi mereka sendiri. Sekarang ini android menjadi sistem operasi paling popular didunia.

Android terbagi atas empat lapisan utama (lihat Gambar 1), yaitu:

a) Linux kernel, dilapisan ini berisikan device tingkatan rendah dari komponen perangkat keras pada android device.

b) Libraries, berisikan semua kode dan menyediakan fitur-fitur utama di android OS.

c) Android runtime berada dilapisan yang sama dengan libraries. Android runtime menyediakan sebuah kumpulan inti libraries yang dapat membuat para pengembang aplikasi android menggunakan java programming.

d) Application framework, membuka berbagai macam kemampuan OS android untuk pengembang aplikasi sehingga mereka dapat 
memakai semuanya diaplikasi yang dibuatnya.

e) Application, berada dilapisan paling atas dan digunakan untuk aplikasi yang berhubungan dengan android device, di mana aplikasi yang diunduh dan diinstall dari pasar android.

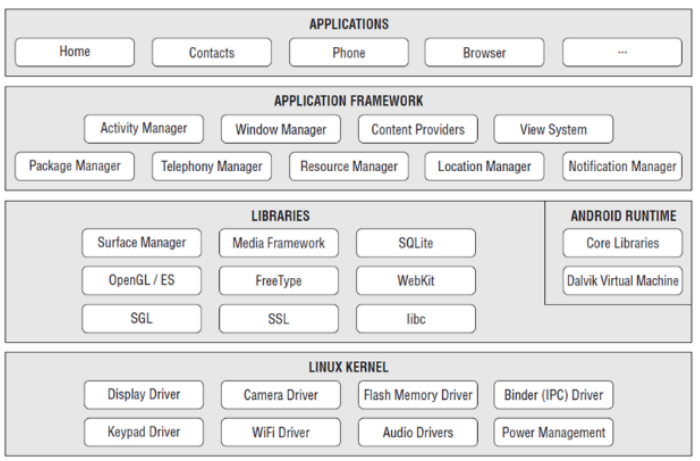

Gambar 1. Arsitektur android ${ }^{[6]}$

D. Ionic Framework

Ionic Framework adalah kerangka pembangunan aplikasi mobile HTML5 yang ditargetkan untuk membangun aplikasi mobile hybrid. Aplikasi hybrid pada dasarnya adalah website yang berjalan dalam browser sebuah aplikasi yang memiliki akses ke lapisan platform native. ${ }^{[7]}$

Ionic framework, merupakan sebuah framework yang berguna untuk mempermudah kita membuat/mengembangkan sebuah aplikasi mobile memakai teknologi web seperti HTML5, CSS, dan Javascript. Selain mudah digunakan ionic juga memiliki tampilan yang menarik karena ionic memakai $u i$ yang telah banyak diterapkan pada aplikasi mobile. Ionic didirikan oleh Maz Lynch, Ben Sperry and Adam Bradley of Drifty Co. pada tahun 2013. Ionic memanfaatkan AngularJS untuk implementasi logicnya karena dengan Angular menawarkan performa dan respon cepat serasa aplikasi native.

\section{a) AngularJS}

AngularJS adalah kerangka struktural untuk aplikasi web dinamis. AngularJS memungkinkan penggunanya menggunakan HTML sebagai bahasa pemrograman yang dipakai dan memungkinkan pengguna memperluas sintaks HTML untuk mengekspresikan komponen aplikasi yang dibuat oleh pengguna dengan jelas dan ringkas. Data binding AngularJS dan dependency injection AngularJS dapat memperingkas proses coding. Dan semua proses tersebut terjadi dalam browser, sehingga AngularJS mampu menjadi pasangan yang ideal dengan teknologi server. AngularJS adalah salah satu bentuk dari HTML bila ingin digunakan untuk mendesain aplikasi. HTML adalah bahasa yang cukup baik untuk dokumen statis. AngularJS adalah kerangka untuk membuat single page application. Dalam pengaplikasiannya AngularJS dapat menghasilkan halaman dinamis tanpa harus membuat banyak halaman web (Wahlin, D., 2013). ${ }^{[8]}$

\section{b) Apache Cordova}

Apache Cordova adalah satu set perangkat API yang memungkinkan pengembang aplikasi mobile untuk mengakses fungsi perangkat native seperti kamera atau accelerometer dari JavaScript perangkat mobile. Dapat dikombinasikan dengan kerangka user interface seperti jQuery Mobile, Dojo Mobile, Sencha Touch, dan lain-lain, mampu memungkinkan aplikasi smartphone untuk dikembangkan dengan hanya HTML, CSS, dan JavaScript (Boedijono, 2015). ${ }^{\text {[9] }}$

\section{c) Hypertext Markup Language}

HTML merupakan bahasa pemrograman standar yang digunakan untuk menampilkan dokumen web. Bahasa yang digunakan HTML terdiri dari teks yang berisi instruksi, dimana teks tersebut adalah tag yang mendefinisikan dengan tepat bagaimana teks dan grafik dapat muncul pada halaman-halaman web Internet. Dengan kata lain, HTML menentukan bagaimana sebuah browser halaman web menampilkan informasi halaman web yang kita buat. HTML adalah sebuah standar yang digunakan secara luas untuk menampilkan halaman web. Saat ini HTML merupakan standar Internet yang didefinisikan dan dikendalikan penggunaannya oleh World Wide Web Consortium (W3C). HTML memiliki beberapa editor yang dapat digunakan dalam pembuatan dokumen web, contohnya notepad, Microsoft Frontpage, dan Macromedia Dreamwaver (Sutraman, 2003). ${ }^{[10]}$

\section{d) Hypertext Preprocessor}

PHP adalah singkatan dari Hypertext Preprocessor. PHP merupakan sebuah bahasa script yang tidak melakukan sebuah kompilasi dalam penggunaannya. PHP dapat berjalan pada web server yang dirilis oleh Microsoft, seperti IIS atau PWS juga Apache yang bersifat open source (Sukarno, 2006). ${ }^{[11]}$

\section{E. Black Box Testing}

Pengujian kotak hitam (Black Box Testing) berfokus pada persyaratan fungsional perangkat lunak. Artinya, teknik pengujian kotak hitam memungkinkan untuk membuat beberapa kumpulan kondisi masukan yang sepenuhnya akan melakukan semua kebutuhan fungsional untuk program. 
Pengujian kotak hitam berupaya untuk menemukan kesalahan dalam kategori berikut:

a) Fungsi yang salah atau hilang.

b) Kesalahan antarmuka.

c) Kesalahan dalam struktur data atau akses basis data eksternal.

d) Kesalahan perilaku atau kinerja.

e) Kesalahan inisialisasi dan penghentian (Pressman, 2010). ${ }^{[12]}$

\section{METODOLOGI PENELITIAN}

Adapun metode pengembangan sistem yang digunakan pada penelitian ini yaitu metode Rapid Application Development (RAD). Rapid Application Development (RAD) adalah salah satu metode pengembangan suatu sistem informasi dengan waktu yang relatif singkat. Untuk pengembangan suatu sistem informasi yang normal membutuhkan waktu minimal 180 hari, akan tetapi dengan menggunakan metode RAD suatu sistem dapat diselesaikan hanya dalam waktu 30-90 hari.

Pada saat RAD diimplementasikan, maka para pemakai bisa menjadi bagian dari keseluruhan proses pengembangan sistem dengan bertindak sebagai pengambil keputusan pada setiap tahapan pengembangan. RAD bisa menghasilkan suatu sistem dengan cepat karena sistem yang dikembangkan dapat memenuhi keinginan dari para pemakai sehingga dapat mengurangi waktu untuk pengembangan ulang setelah tahap implementasi (Noertjahyana, 2002). ${ }^{[13]}$

Ada 4 tahapan yang harus dilakukan pada metodologi RAD yaitu analisis persyaratan, analisis modeling, desain modeling dan konstruksi :

\section{a) Analisis Persyaratan}

Tahap ini bertujuan untuk mengidentifikasi kebutuhan pengguna, spesifikasi sistem melalui observasi dan pengumpulan data yang dilakukan terhadap stakeholders, sehingga aplikasi yang akan dibuat akan sesuai dengan yang dibutuhkan oleh pengguna.

\section{b) Analisis Modeling}

Tujuan dari fase analisis modeling adalah menganalisa semua kegiatan dalam arsitektur sistem secara keseluruhan dengan melibatkan identifikasi dan deskripsi abstraksi sistem perangkat lunak yang mendasar dan hubungan-hubungannya. Selain itu, analisis modeling juga bertujuan untuk meningkatkan pemahaman terhadap permasalahan tanpa mempertimbangkan solusi teknis. Hasil akhir dari analisis modeling yaitu diagram model logis sistem yang sedang berjalan, diantaranya use case diagram, activity diagram, class diagram, dan sequence diagram. c) Desain Modelling

Tujuan dari fase desain modeling yaitu melakukan perancangan sistem berdasarkan analisis yang telah dilakukan sebelumnya. Tahap analisis dan desain mengalami perulangan hingga diperoleh rancangan sistem yang benar-benar memenuhi kebutuhan. Selain itu, fase ini juga bertujuan untuk memberikan spesifikasi yang jelas dan lengkap kepada programmer dan teknisi. Hasil akhir dari fase ini yaitu basis data, antarmuka, dan spesifikasi desain. ${ }^{[13]}$

\section{d) Konstruksi}

Tujuan dari fase konstruksi adalah untuk menunjukkan platform, hardware dan software yang digunakan serta batasan dalam implementasi, serta menguji performansi prototipe perangkat lunak yang telah dibangun agar dapat diketahui apakah prototipe tersebut telah sesuai dengan spesifikasi analisis dan perancangan yang telah diidentifikasi sebelumnya.

\section{HASIL DAN PEMBAHASAN}

\section{A. Tahap Analisis Persyaratan}

Fase Analisis Persyaratan merupakan proses melakukan pengumpulan data atau bahan dan mengidentifikasi layanan, batasan, dan obyektivitas dari pengumpulan data yang dilakukan.

Hasil dari proses ini berupa laporan penelitian dari pengembangan aplikasi, analisis spesifikasi awal, analisis persyaratan user dan sistem, dan informasi fitur pada aplikasi.

\section{a) Rencana Kerja}

Langkah pertama dalam pembuatan aplikasi ini yaitu menyusun rencana kerja. Ini berguna agar setiap proses yang dilakukan dalam pembuatan aplikasi jelas dan terstruktur. Rencana kerja pembuatan aplikasi ini dapat dilihat pada Gambar 2 berikut ini.

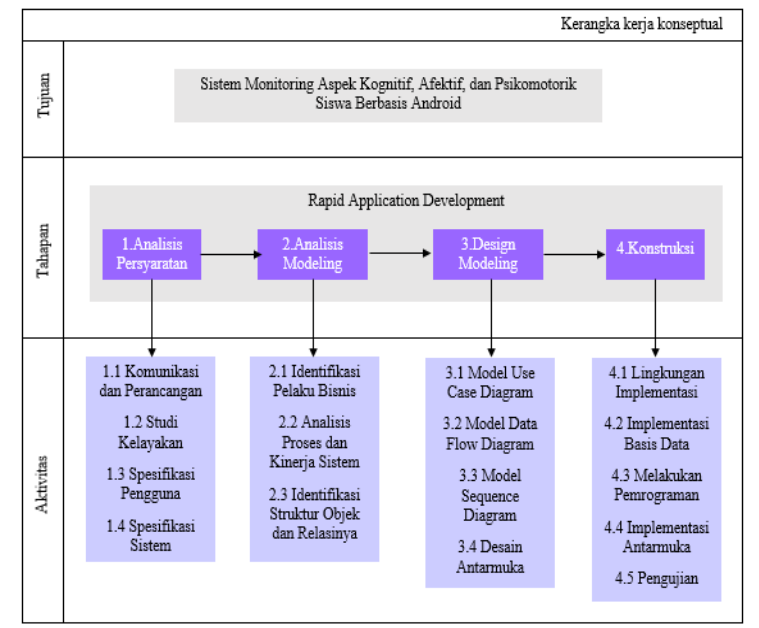

Gambar 2. Rencana Kerja 
b) Manajemen Resiko

Dalam setiap proyek, tentu saja diperhadapkan dengan berbagai macam resiko. Tabel 1 berikut adalah resiko yang mungkin terjadi dalam pengembangan aplikasi.

Tabel 1. Manajemen Resiko

\begin{tabular}{|l|l|l|l|}
\hline \multicolumn{1}{|c|}{ Risk } & \multicolumn{1}{c|}{ Contigency } & \multicolumn{1}{c|}{ Cause } & \multicolumn{1}{c|}{ Effect } \\
\hline $\begin{array}{l}\text { Perubahan } \\
\text { jadwal. }\end{array}$ & $\begin{array}{l}\text { Penyesuaian } \\
\text { jadwal } \\
\text { kembali. }\end{array}$ & $\begin{array}{l}\text { Keterlamba } \\
\text { tan. }\end{array}$ & $\begin{array}{l}\text { Waktu } \\
\text { lebih lama. }\end{array}$ \\
\hline $\begin{array}{l}\text { Kesalahan } \\
\text { pemrogram } \\
\text { an. }\end{array}$ & $\begin{array}{l}\text { Perbaikan } \\
\text { kesalahan } \\
\text { pemrograman. }\end{array}$ & $\begin{array}{l}\text { Ketidak- } \\
\text { telitian. }\end{array}$ & $\begin{array}{l}\text { Keterlamba } \\
\text { tan dan } \\
\text { performa } \\
\text { yang tidak } \\
\text { maksimal. }\end{array}$ \\
\hline $\begin{array}{l}\text { Perubahan } \\
\text { persyaratan } \\
\text { pengguna. }\end{array}$ & $\begin{array}{l}\text { Pemrograman } \\
\text { kembali. }\end{array}$ & $\begin{array}{l}\text { Keinginan } \\
\text { user yang } \\
\text { berubah- } \\
\text { ubah. }\end{array}$ & $\begin{array}{l}\text { Keterlamba } \\
\text { tan dan } \\
\text { performa } \\
\text { program } \\
\text { yang tidak } \\
\text { maksimal. }\end{array}$ \\
\hline $\begin{array}{l}\text { Kesalahan } \\
\text { analisis } \\
\text { sistem. }\end{array}$ & $\begin{array}{l}\text { Analisis } \\
\text { kembali dan } \\
\text { terjadi } \\
\text { perombakkan } \\
\text { desain. }\end{array}$ & $\begin{array}{l}\text { Keinginan } \\
\text { user yang } \\
\text { tidak } \\
\text { teridentifik } \\
\text { asi dengan } \\
\text { baik. }\end{array}$ & $\begin{array}{l}\text { Perubahan } \\
\text { fitur. }\end{array}$ \\
\hline
\end{tabular}

c) Spesifikasi Pengguna

Langkah ini merupakan langkah mengidentifikasi dan menetapkan kebutuhan-kebutuhan pengguna. Hasil dari daftar pengguna beserta tugasnya dapat dilihat pada Tabel 2 dibawah ini.

Tabel 2. Daftar Pengguna dan Tanggung Jawabnya

\begin{tabular}{|l|ll|}
\hline Pengguna & \multicolumn{2}{|c|}{ Tugas dan Tanggung Jawab } \\
\hline Kagian & 1. & $\begin{array}{l}\text { Menyimpan laporan guru dari tiap siswa } \\
\text { ke dalam komputer }\end{array}$ \\
& $\begin{array}{l}\text { 2. } \\
\text { 3emperbarui data - data laporan yang ada } \\
\text { Merekap data - data laporan di akhir } \\
\text { semester }\end{array}$ \\
\hline Guru & $\begin{array}{ll}\text { Menginput data berupa laporan kepada } \\
\text { bagian kesiswaan } \\
\text { Melihat data yang telah diinput. }\end{array}$ \\
\hline
\end{tabular}

\section{B. Tahap Analisis Modelling}

Fase berikutnya adalah fase analisis modeling yang bertujuan menganalisis semua kegiatan dalam arsitektur sistem secara keseluruhan dengan cara identifikasi dan abstraksi sistem yang mendasar. Proses yang dilakukan dimulai dari mengidentifikasi aktor dan use case dengan merancang aplikasi yang akan dikembangkan, menggambarkan aliran control untuk mengetahui hubungan aktor dan objek, menggambarkan komunikasi antar objek dan aktor, menggambarkan perubahan keadaan suatu objek pada aplikasi kelas tertentu, memodelkan prilaku use case serta objek pada aplikasi dan menggambarkan perubahan suatu objek pada kelas tertentu.

a) Mengidentifikasi Pelaku Bisnis
Identifikasi para pelaku bisnis ato para pengguna aplikasi merupakan salah satu proses penting dalam pembuatan aplikasi sehingga para programmer tau siapa saja yang akan menggunakan aplikasi yang akan dibuat. Tabel 3 berikut merupakan daftar pelaku bisnis yang ada pada aplikasi yang akan di buat.

Tabel 3. Daftar Aktor Beserta Tugas dan Tanggung Jawabnya

\begin{tabular}{|c|c|}
\hline Aktor & Tugas dan Tanggung Jawab \\
\hline $\begin{array}{l}\text { Admin } \\
\text { (Web App - } \\
\text { Server side) }\end{array}$ & $\begin{array}{l}\text { 1. Mengatur database berupa penambahan } \\
\text { data, edit data, dan hapus data } \\
\text { 2. Mengubah username dan password user. } \\
\text { 3. Merekap data untuk dijadikan bahan } \\
\text { evaluasi }\end{array}$ \\
\hline $\begin{array}{l}\text { User } \\
\text { (Android } \\
\text { App - } \\
\text { Client side) }\end{array}$ & $\begin{array}{l}\text { 1. Menambah data, poin, dan catatan dari } \\
\text { tiap siswa } \\
\text { 2. Melihat informasi lengkap dari tiap } \\
\text { siswa } \\
\text { 3. Mengevaluasi siswa berdasarkan } \\
\text { informasi lengkap dari aplikasi }\end{array}$ \\
\hline
\end{tabular}

b) Use Case Diagram

Use case diagram terdiri dari dua aktor yaitu user dan admin dimana user dan admin ini mengakses dua aplikasi yang berbeda (dapat dilihat pada Gambar 3). User mengakses aplikasi android (android app) dimana aplikasi android ini didalamnya sudah termasuk fitur login dan terhubung dengan aplikasi web (web app) sedangkan admin mengakses aplikasi web dimana aplikasi web ini didalamnya sudah termasuk database, fitur login dan terhubung dengan aplikasi android.

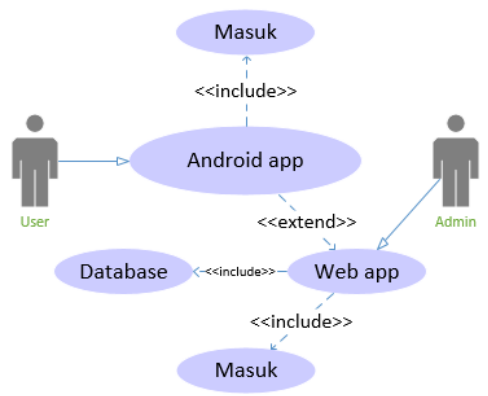

Gambar 3. Use Case Aplikasi Monitoring

C. Tahap Desain Modeling

Pada fase desain modeling aplikasi sistem monitoring siswa dikembangkan berdasarkan analisis yang dilakukan pada fase analisis modeling sebelumnya. Pada tahapan analisis dan desain modeling mengalami perulangan bertujuan untuk medapatkan hasil perancangan sistem yang benarbenar memenuhi kebutuhan. Hasil dari fase ini adalah basis data, antarmuka dan spesifikasi desain.

\section{Model Use Case Diagram}


Use case pada android app, dimana user dapat melakukan proses monitoring dengan menginput data, dan melihat data. Data hasil inputan user ini akan secara otomatis tersimpan ke dalam database sedangkan untuk melihat data, aplikasi akan secara langsung meminta data dari database untuk ditampilkan ke layar. Untuk membuat aplikasi ini menjadi lebih menarik ada pilihan untuk melihat profil dan tentang aplikasi. Profil berisi biodata dari user yang sedang login dan tentang aplikasi berisi deskripsi singkat mengenai aplikasi monitoring ini. Untuk menjaga keamanan dan kerahasiaan dari aplikasi ini tentunya setiap kali user akan menggunakan atau mengakhiri aplikasi, akan ada proses login (masuk) dan logout (keluar) aplikasi. Gambar 4 berikut adalah model use case diagram client side aplikasi:

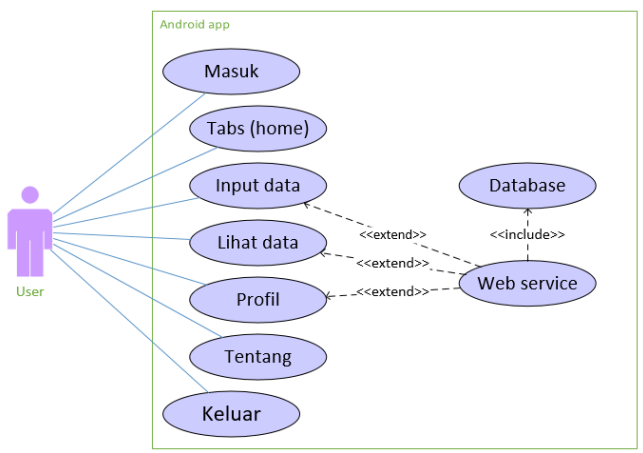

Gambar 4. Use Case Diagram Client Side

Gambar 5 berikut menggambarkan Use Case pada sisi Back-End (server). Sebelum menggunakan aplikasi, admin terlebih dahulu harus melakukan proses login untuk proses verifikasi. Apabila login sukses admin dapat melakukan CRUD (Create, Read, Update, Delete) atas database siswa, database guru, dan database poin siswa.

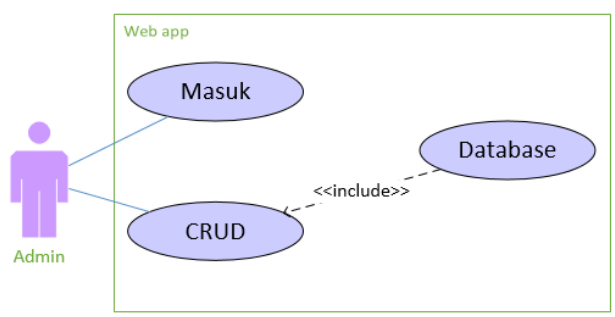

Gambar 5. Use Case Diagram Server Side

\section{Tahap Konstruksi}

Fase konstruksi ini merupakan tahapan pembuatan aplikasi yang mengacu pada tahapan sebelumnya dimana untuk menunjukan platform, hardware dan software yang digunakan serta batasan dalam implementasi dan menguji performansi dari aplikasi yang akan dikembangkan. a) Implementasi Antar Muka

Saat aplikasi android dibuka maka akan masuk pada tampilan Login seperti pada Gambar 6 berikut. User diwajibkan mengisi username dan password agar dapat mengakses aplikasi lebih dalam. Jika berhasil, user akan lanjut ke tampilan tab menu (beranda aplikasi), sebaliknya jika user gagal melakukan login akan muncul pesan kesalahan.

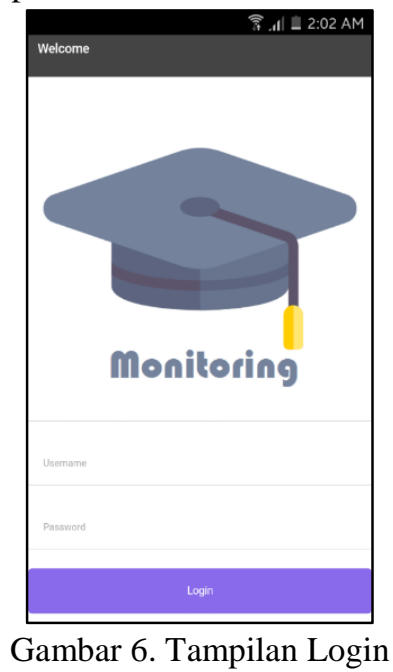

Aplikasi ini menggunakan ionic framework dengan tema "tabs" dimana navigasi utama aplikasi ini adalah tab - tab menu yang berada pada bagian bawah aplikasi (footer). Konsep dari ionic dengan tema tabs yaitu tema ini tidak memiliki beranda utama. Aplikasi monitoring siswa ini memiliki tiga tab menu utama yaitu; lapor, cari, dan tentang.

Tab lapor dipilih jika user ingin menambah data siswa. Tab lapor akan menampilkan daftar kelas untuk dipilih oleh guru (user) sesuai dengan kelas siswa yang ingin ditambahkan datanya seperti pada Gambar 7 berikut ini.

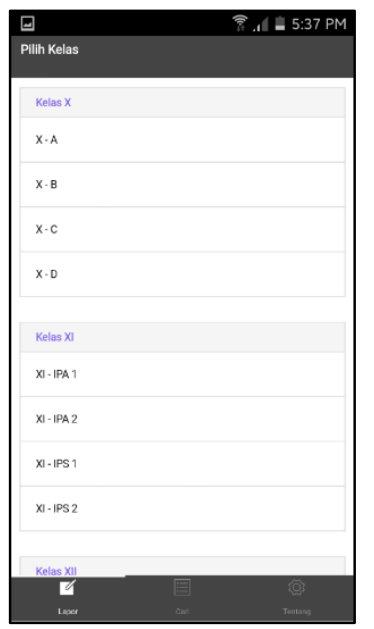

Gambar 7. Tampilan Tab Lapor 
Ketika user selesai memilih kelas, maka user akan melihat daftar siswa dari kelas yang user pilih. Halaman pilih siswa akan menampilkan daftar siswa yang ada dalam kelas tersebut meliputi nama siswa, nomor induk siswa, dan foto siswa yang dapat dilihat pada Gambar 8 berikut ini.

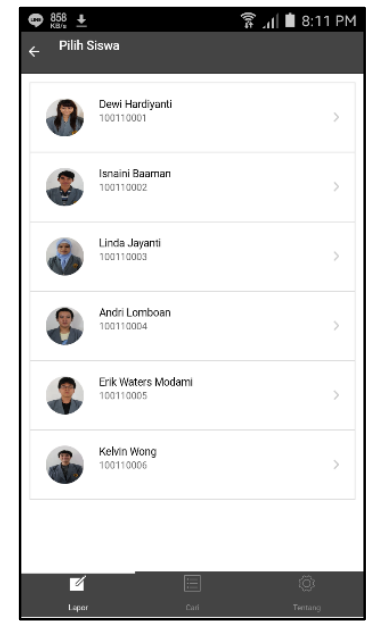

Gambar 8. Tampilan Pilih Siswa

Selesai memilih siswa dari kelas tertentu maka user akan masuk ke tampilan buat laporan dimana user bisa menginput data kognitif, afektif, atau psikomotorik siswa (lihat Gambar 9). Bagian atas halaman buat laporan akan menampilkan foto beserta data singkat dari siswa, sedangkan bagian bawah aplikasi akan menampilkan form inputan data siswa. Andaikata user memilih kognitif, maka akan muncul form isian data kognitif meliputi semester, subject, poin, catatan dan terakhir tombol submit.

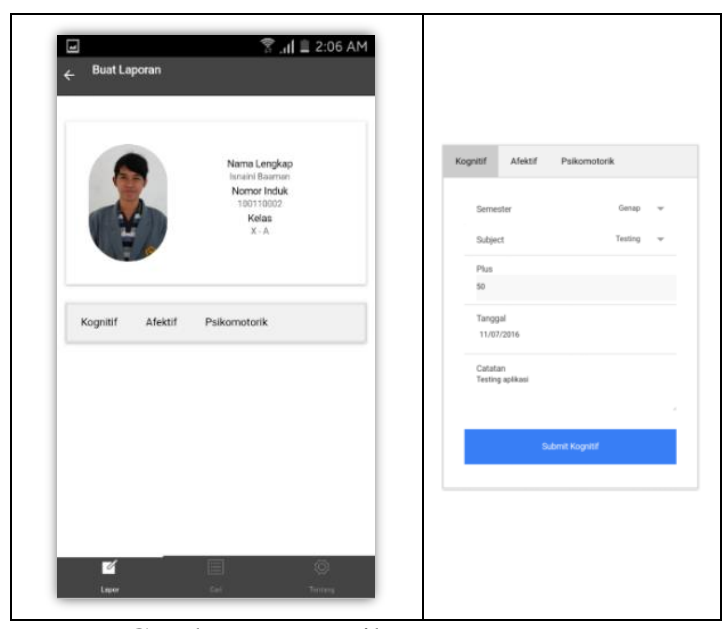

Gambar 9. Tampilan Buat Laporan

Tab menu yang kedua adalah cari. Ketika user memilih tab menu cari maka akan tampil pada layar yaitu tampilan cari (lihat Gambar 10). Halaman cari berguna ketika user ingin melihat data - data yang ada pada siswa, data ini bisa dijadikan evaluasi atas siswa tersebut karena data yang diambil dari database ini bersifat valid. User bisa memilih salah satu siswa dengan melihat ataupun menggeser kebawah guna mencari siswa yang diinginkan. Cara lain untuk mencari siswa yang user cari bisa dengan memanfaatkan fitur search yang ada pada aplikasi.

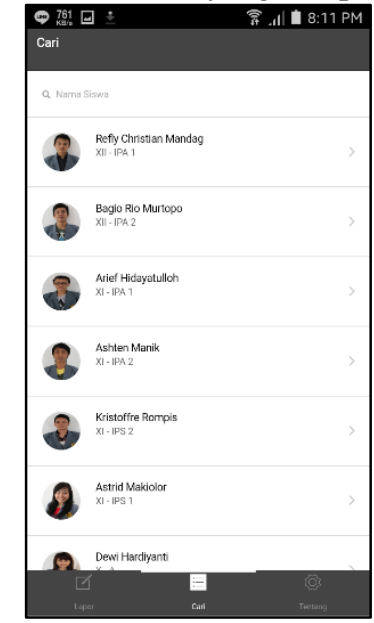

Gambar 10. Tampilan Tab Cari

Tampilan detail siswa yang ada pada Gambar 11 berikut ini memiliki kemiripan dengan tampilan buat laporan. Pada bagian atas terdapat foto dan profil singkat tentang siswa dan pada bagian bawah terdapat data siswa berdasarkan aspek dan berdasarkan semester. Setelah user memilih aspek dan memilih semester maka sistem akan menampilkan data siswa juga tombol untuk melihat hasil penilaian dari aspek siswa tersebut.

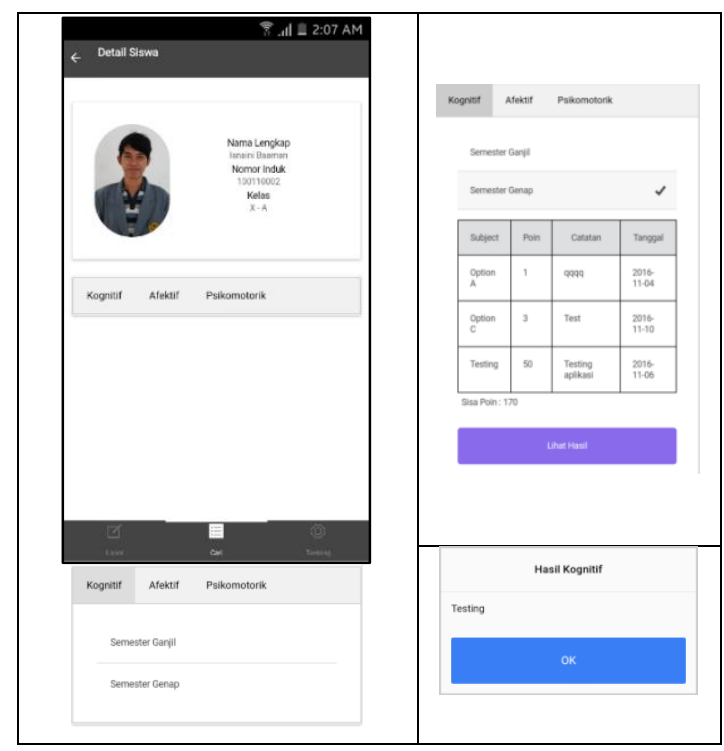

Gambar 11. Tampilan Detail Siswa

Tab menu yang ketiga adalah tampilan tentang yang menampilkan profil user, tentang aplikasi dan 
tombol logout. Untuk hasil dari tampilan tentang dapat dilihat pada Gambar 12 .

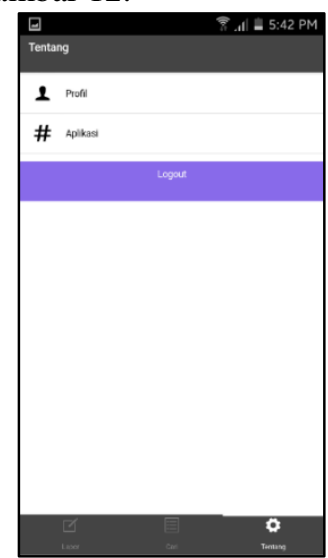

Gambar 12. Tampilan Tab Tentang

Ketika user memilih profil pada halaman tentang maka user dapat melihat profil user. Profil user terdiri dari foto user, nama lengkap, nip, tempat dan tanggal lahir, jenis kelamin, jabatan, dan guru matapelajaran yang dapat dilihat pada Gambar 13 berikut ini.

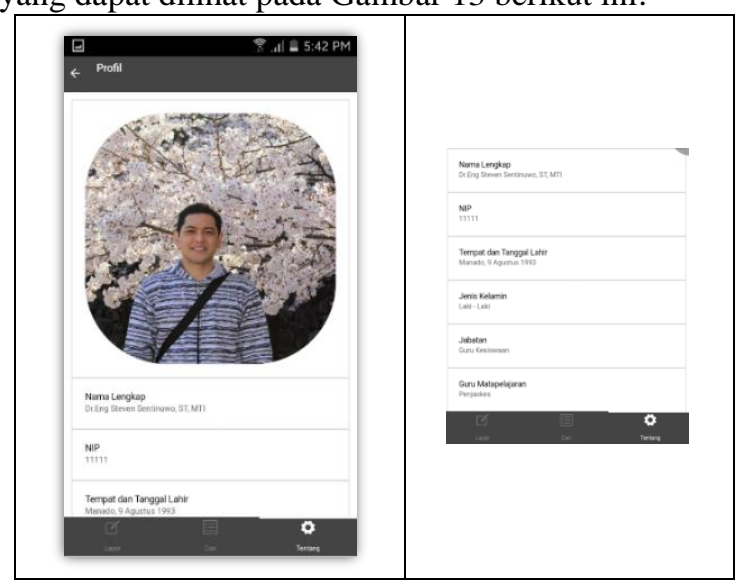

Gambar 13. Tampilan Profil

Jika user memilih aplikasi pada tab-menu tentang maka user akan melihat ikon aplikasi beserta deskripsi singkat mengenai aplikasi ini (lihat Gambar 14).

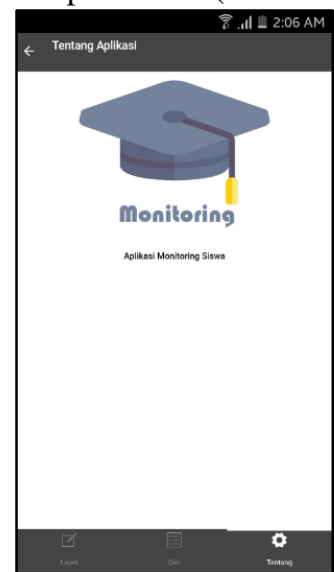

Gambar 14. Tampilan Tentang Aplikasi b) Pengujian Sistem

Pada tahap pengujian sistem monitoring siswa ini hanya diterapkan pada black box testing. Pengujian dilakukan pada aplikasi android dan web, untuk android dijalankan pada perangkat Samsung Galaxy A5 dan untuk web dijalankan pada browser Google Chrome.

Pengujian pada aplikasi android meliputi login, fungsi input data kognitif, fungsi input data afektif, fungsi input data psikomotorik, lihat data, dan logout. Untuk poin pengujian dapat dilihat pada Tabel 4 berikut.

Tabel 4. Tabel Pengujian Aplikasi Android

\begin{tabular}{|c|c|}
\hline No & Titik Pemeriksaan \\
\hline \multirow[t]{2}{*}{1.} & Testing login. \\
\hline & $\begin{array}{l}\text { Apakah username dan password yang dimasukkan } \\
\text { dapat dibaca oleh sistem? }\end{array}$ \\
\hline \multirow[t]{5}{*}{2.} & Testing fungsi input data kognitif. \\
\hline & $\begin{array}{l}\text { Apakah aplikasi dapat mengirim data bila tidak } \\
\text { memilih semester? }\end{array}$ \\
\hline & $\begin{array}{l}\text { Apakah aplikasi dapat mengirim data bila salah satu } \\
\text { form atau lebih tidak diisi? }\end{array}$ \\
\hline & $\begin{array}{l}\text { Apakah aplikasi dapat mengirim data bila form plus } \\
\text { tidak diisi dengan angka? }\end{array}$ \\
\hline & $\begin{array}{l}\text { Apakah ada popup konfirmasi untuk memperingati } \\
\text { user dalam mengirim data? }\end{array}$ \\
\hline \multirow[t]{5}{*}{3.} & Testing fungsi input data afektif. \\
\hline & $\begin{array}{l}\text { Apakah aplikasi dapat mengirim data bila tidak } \\
\text { memilih semester? }\end{array}$ \\
\hline & $\begin{array}{l}\text { Apakah aplikasi dapat mengirim data bila salah satu } \\
\text { form atau lebih tidak diisi? }\end{array}$ \\
\hline & $\begin{array}{l}\text { Apakah aplikasi dapat mengirim data bila form minus } \\
\text { tidak diisi dengan angka? }\end{array}$ \\
\hline & $\begin{array}{l}\text { Apakah ada popup konfirmasi untuk memperingati } \\
\text { user dalam mengirim data? }\end{array}$ \\
\hline \multirow[t]{5}{*}{4.} & Testing fungsi input data psikomotorik. \\
\hline & $\begin{array}{l}\text { Apakah aplikasi dapat mengirim data bila tidak } \\
\text { memilih semester? }\end{array}$ \\
\hline & $\begin{array}{l}\text { Apakah aplikasi dapat mengirim data bila salah satu } \\
\text { form atau lebih tidak diisi? }\end{array}$ \\
\hline & $\begin{array}{l}\text { Apakah aplikasi dapat mengirim data bila form plus } \\
\text { tidak diisi dengan angka? }\end{array}$ \\
\hline & $\begin{array}{l}\text { Apakah ada popup konfirmasi untuk memperingati } \\
\text { user dalam mengirim data? }\end{array}$ \\
\hline \multirow[t]{4}{*}{5.} & Testing lihat data. \\
\hline & Apakah sistem dapat menampilkan data siswa? \\
\hline & $\begin{array}{l}\text { Apakah sistem dapat membagi data yang dilihat } \\
\text { berdasarkan semester? }\end{array}$ \\
\hline & $\begin{array}{l}\text { Apakah data yang dilihat sesuai dengan data yang } \\
\text { diinput user? }\end{array}$ \\
\hline 6. & Testing lihat profil \\
\hline \multirow[t]{3}{*}{7.} & Testing logout. \\
\hline & $\begin{array}{l}\text { Apakah sistem menampilkan konfirmasi pertanyaan } \\
\text { untuk logout? }\end{array}$ \\
\hline & $\begin{array}{l}\text { Apakah sistem menampilkan halaman masuk setelah } \\
\text { keluar berhasil? }\end{array}$ \\
\hline
\end{tabular}




\section{KESIMPULAN DAN SARAN}

A. Kesimpulan

Kesimpulan akhir dari pembuatan sistem monitoring kognitif, afektif, dan psikomotorik siswa berbasis android adalah sebagai berikut:

a) Aplikasi ini mampu menjawab kelemahan kelemahan yang ada pada proses monitoring yang diterapkan sekolah saat ini seperti integritas data, keamanan data, dan single user.

b) Aplikasi monitoring siswa dapat menjadi alat bantu para guru dalam memonitoring aspek kognitif, afektif, dan psikomotorik siswa di sekolah.

c) Metodologi Rapid Application Development ( $R A D$ ) dapat digunakan untuk membangun aplikasi mobile berbasis android. Aplikasi ini juga dapat berjalan

B. Saran dengan baik pada semua perangkat android.

Aplikasi sistem monitoring ini dirancang khusus untuk digunakan oleh para guru di sekolah. Saran untuk pengembangan selanjutnya agar dapat dibuatkan versi aplikasi dengan sistem operasi iOs (iphone Operating System) untuk aplikasi ini.

\section{DAFTAR PUSTAKA}

[1] Bloom, Benjamin S. dkk. 1956. Taxonomy of Educational Objectives : The Classification of Educational Goals, Handbook I Cognitive Domain. New York : Longmans, Green and Co.

[2] Solichin, M. M. 2012. Psikologi Belajar: Aplikasi Teori-Teori Belajar Dalam Proses Pembelajaran. Yogyakarta: Suka Press.

[3] Andersen, L. W. 1981. Assessing affective characteristic in the schools. Boston: Allyn and Bacon.

[4] Haryati, M. 2009. Model Dan Teknik Penilaian Pada Tingkat Satuan Pendidikan. Jakarta: Gaung Persada Press.

[5] Soekartawi. 1995. Monitoring dan Evaluasi Proyek Pendidikan. Jakarta: PT. Dunia Pustaka Jaya.

[6] Lee, Wei-Meng. 2011. Beginning Android Application Development. Indianapolis: Wiley Publishing,Inc.

[7] Ionic Framework, Guide. http://ionicframework.com/docs/guide/preface.ht $\mathrm{ml}, 17$ Oktober 2016.

[8] Wahlin, D. 2013. AngularJS. Arizona: Wahlin Consulting.

[9] Boedijono, H. 2015. Pembuatan Aplikasi News Dwi Pekan Universitas Kristen Petra Berbasis Android. Vol.3 No 2.
[10] Sutraman. 2003. Membangun Aplikasi Web dengan PHP dan MySQL. Graha Ilmu, Yogyakarta.

[11] Sukarno, M. 2006. Membangun Website Dinamis Interaktif dengan PHP-MySQL (Windows \& Linux). Jakarta: Esk Media.

[12] Pressman, R.S. 2010. Rekayasa Perangkat Lunak buku 1. edisi 7, terjemahan Tim Penerjemah Andi, Yogyakarta: Andi.

[13] Tim Pengembang Portal Resmi UNSRAT. 2015. Laporan Akhir RAD Pembangunan Portal Resmi Universitas Sam Ratulangi Manado

[14] Tim Penyusun Panduan Penulisan KTIS Fakultas Teknik UNSRAT. 2006. Panduan Penulisan Karya Tulis Ilmiah Sarjana (KTIS) Universitas Sam Ratulangi Manado Fakultas Teknik

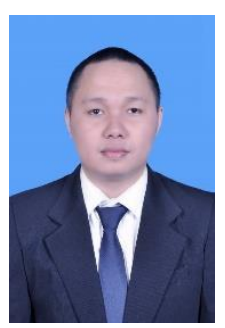

Sekilas dari penulis dengan nama lengkap Lorenzo Maximilian Kasenda, lahir di Remboken, Kabupaten Minahasa, Provinsi Sulawesi Utara. Anak ke-3 dari 3 bersaudara dengan pendidikan Sekolah Dasar Katolik Remboken. Penulis lalu melanjutkan ke Sekolah Menengah Pertama Negeri 1 Remboken. Lalu ke SMA Katolik Santo Thomas Aquino Manado. Pada tahun 2011 melanjutkan ke Perguruan Tinggi di Universitas Sam Ratulangi dengan mengambil Jurusan Teknik Informatika. Pada Tahun 2016 bulan Mei, penulis membuat Skripsi demi memenuhi syarat Sarjana (S1) dengan penelitian berjudul Sistem Monitoring Kognitif, Afektif dan Psikomotorik Siswa Berbasis Android yang dibimbing oleh dua dosen pembimbing yaitu Dr. Eng Steven R. Sentinuwo, ST., MTI dan Virginia Tulenan S.Kom, MTI sehingga pada tanggal 1 Desember 2016 penulis resmi lulus di Teknik Informatika Universitas Sam Ratulangi Manado menyandang gelar sarjana komputer dengan predikat sangat memuaskan. 